\title{
Worsening of the COVID-19 Pandemic in New York City: Analysis of Response Gaps and Challenges at the Public Policy and Community Levels
}

\author{
Aysha Zahidie $^{1}$, Meesha lqbal ${ }^{2}$ and Syed Wasif Hussain ${ }^{3}$ \\ ${ }^{1}$ Independent Researcher, New York City, NY, USA \\ ${ }^{2}$ Independent Researcher, Idaho Falls, Idaho, USA \\ ${ }^{3}$ SUNY Downstate Medical Centre, New York City, NY, USA
}

\begin{abstract}
This review was aimed to probe into factors that resulted in worsening of novel coronavirus disease 2019 (COVID-19) pandemic in New York City, USA. Extensive review of available information sources, such as scientific literature, COVID-19 data generating websites, expert opinions as well as government briefings and simultaneous measures, were carried out to fulfil the objectives of this paper. Data was arranged in tabular form. Gaps in responding to the pandemic were identified. There was lack of proactivity in measures taken by governments which is due to neo-liberal capitalism on one hand and lack of coordination among three tiers of government on the other. Cosmopolitan features of the city also made it prone to devastating spread of pandemic. Crowded mega cities with incompetent governments in implementing timely public health measures for prevention of spread of COVID-19 are at potential threat of high disease spread across the globe.
\end{abstract}

Keywords: New York City, COVID-19 pandemic, Response gaps, Metropolitan.

How to cite this article: Zahidie A, Iqbal M, Hussain SW. Worsening of the COVID-19 Pandemic in New York City: Analysis of Response Gaps and Challenges at the Public Policy and Community Levels. J Coll Physicians Surg Pak 2020; 30(JCPSPCR):CR32-CR36 https://doi.org/10.29271/jcpsp.2020.JCPSPCR.CR32.

\section{INTRODUCTION}

Since its emergence in Wuhan, China, the novel coronavirus disease 2019 (COVID-19) has continued to shift its epicenter westward, gravely affecting countries such as Iran, Italy, UK, Spain, and the USA. ${ }^{1,2}$ Eight weeks after an early outbreak in Washington state, COVID-19 swept across the country, infecting 652,474 people and taking 32,712 lives, as of April 15, $2020{ }^{1,3}$

By the end of March 2020, the US had the highest number of COVID cases in the world (111,980 confirmed cases, and 1,697 deaths), and by mid-April 2020, New York state alone held this position. ${ }^{1,4}$ By the end of second week of April, New York state reported the highest number of cases $(213,779$ confirmed cases, and 11,586 deaths), accounting for $33 \%$ of the morbidity and $35 \%$ of the mortality rates in the country. More than $50 \%$ of the cases in New York state originated in New York City (NYC) (118,302 confirmed cases, and 10,367 deaths) by April 15, $2020{ }^{1}$

Correspondence to: Dr. Aysha Zahidie, 2790 e 65 street, Brooklyn, New York, NY 11234, USA

E-mail: ayshazahidie@outlook.com

Received: May 12, 2020; Revised: June 25, 2020;

Accepted: June 26, 2020

DOI: https://doi.org/10.29271/jcpsp.2020.JCPSPCR.CR32
NYC, being a financial hub and vibrant tourist spot, shares many common characteristics with other cosmopolitan cities. The pluralistic features of being an international city played a major role in the COVID-19 pandemic overwhelming NYC. We aimed to identify the factors leading to this along with gaps and challenges while responding to a pandemic and the ensuing high casualties and economic paralysis of NYC.

\section{METHODOLOGY}

Extensive review of available information sources such as scientific literature, COVID-19 data generating websites, expert opinions as well as government briefings and simultaneous measures was carried out to fulfil the objectives of this paper. Data was arranged in tabular form with critical analysis of each of government measures and its impact on mitigation of COVID-19 pandemic (Table I). Gaps and challenges in responding to the pandemic were identified at the policy and community levels and presented in subsequent tables (Tables॥A\&॥B).

\section{RESULTS AND DISCUSSION}

\section{Advent of COVID-19 in NYC, USA:}

The first case in New York state was reported in NYC on March 1, 2020, followed by a second case on March 3, 2020 in Westchester County, north of NYC. By March 6, the number of cases had increased to 33, of which more than 20 were related to the second case. By mid-March, the number of confirmed cases rose to 613. Between March 22 and 23, 2020, confirmed cases increased by 4,000 , reaching a total of 21,000 statewide. . $^{3,4}$ 
Table I: Timeline of the government's responses to COVID-19 in New York state with a subsequent increase in reported cases.

\begin{tabular}{|c|c|c|c|c|}
\hline Date & $\begin{array}{l}\text { Cases in } \\
\text { NYC }\end{array}$ & $\begin{array}{l}\text { Cases in } \\
\text { rest of New } \\
\text { York }\end{array}$ & Measures & Application \\
\hline Jan 31, 2020 & 0 & 0 & $\begin{array}{l}\text { The federal government imposed travel } \\
\text { restrictions preventing foreign nationals from } \\
\text { entering the USA if they had been in China } \\
\text { within the previous two weeks. }\end{array}$ & $\begin{array}{l}\text { NYC houses the largest Chinese population outside of Asia } \\
(682,265 \text { individuals, Census } 2010) .{ }^{9} \text { Many of these Chinese } \\
\text { residents are US citizens traveling to and from China. This } \\
\text { measure did not restrict them from re-entering the USA. }\end{array}$ \\
\hline Mar 5, 2020 & 4 & 11 & $\begin{array}{l}\text { The city government refused to advise people } \\
\text { to avoid public transport. }\end{array}$ & $\begin{array}{l}\text { NYC's mayor took a ride on a subway train with the press to } \\
\text { boost people's confidence in using city transport. }\end{array}$ \\
\hline Mar 7, 2020 & 11 & 65 & $\begin{array}{l}\text { A "state of emergency" was declared by the } \\
\text { state. }\end{array}$ & $\begin{array}{l}\text { NYC issued guidelines asking sick individuals to avoid using } \\
\text { public transport and heavily packed buses. }\end{array}$ \\
\hline Mar 10, 2020 & 36 & 137 & $\begin{array}{l}\text { New Rochelle, Westchester County, was } \\
\text { announced as a "containment zone." }\end{array}$ & $\begin{array}{l}\text { Law enforcement agencies were appointed to facilitate the } \\
\text { community. }\end{array}$ \\
\hline Mar 11, 2020 & 52 & 164 & $\begin{array}{l}\text { The closure of the City and State Universities } \\
\text { of New York was announced to be started from } \\
\text { next week. }\end{array}$ & Online classes were to be started on March 19. \\
\hline Mar 12, 2020 & 95 & 230 & $\begin{array}{l}\text { Restrictions were implemented on mass } \\
\text { gatherings. }\end{array}$ & $\begin{array}{l}\text { Events with }>500 \text { people were asked to be postponed, and } \\
\text { events with }<500 \text { people were asked to cut capacity by } 50 \% \text {. }\end{array}$ \\
\hline Mar 16, 2020 & 463 & 487 & $\begin{array}{l}\text { The White House recommended "social } \\
\text { distancing," which included closing of schools } \\
\text { and avoiding gatherings of more than ten } \\
\text { people. }\end{array}$ & $\begin{array}{l}\text { States were not constitutionally bound to adopt federal } \\
\text { guidelines. }\end{array}$ \\
\hline Mar 17, 2020 & 644 & 730 & $\begin{array}{l}\text { NYC's mayor announced that the city was } \\
\text { considering a shelter-in-place order within the } \\
\text { next } 48 \text { hours. }\end{array}$ & $\begin{array}{l}\text { The mayor's comments were quickly dispelled by the office of } \\
\text { the state governor declaring, "No city in this state can } \\
\text { quarantine itself without state approval...." }\end{array}$ \\
\hline Mar 18, 2020 & 1339 & 1043 & New York ordered all schools to remain closed. & $\begin{array}{l}\text { Promotion to the next grade level was planned without formal } \\
\text { assessment. }\end{array}$ \\
\hline Mar 20, 2020 & 4408 & 2694 & $\begin{array}{l}\text { The mayor called for drastic measures to } \\
\text { combat the outbreak. "We have to go to a } \\
\text { shelter-in-place model." }\end{array}$ & $\begin{array}{l}\text { "New York State on Pause Program" was announced, } \\
\text { implementing a statewide stay-at-home order, starting March } \\
22,2020 .\end{array}$ \\
\hline Mar 22, 2020 & 9045 & 6123 & $\begin{array}{l}\text { Non-essential workers were ordered to stay at } \\
\text { home. }\end{array}$ & \\
\hline Mar 22, 2020 & 9045 & 6123 & $\begin{array}{l}\text { The federal government directed the Federal } \\
\text { Emergency Management Agency to New York } \\
\text { State for medical relief. }\end{array}$ & $\begin{array}{l}\text { Four large federal medical stations with 1,000 beds were } \\
\text { allocated for New York. }\end{array}$ \\
\hline Mar 23, 2020 & 12305 & 8570 & $\begin{array}{l}\text { The state announced a plan to use } \\
\text { convalescent antibody-rich blood plasma as a } \\
\text { possible passive immunization. }\end{array}$ & \\
\hline Mar 24, 2020 & 14904 & 10761 & $\begin{array}{l}\text { The White House coronavirus response } \\
\text { coordinator advised people who arrived in } \\
\text { other areas from NYC to self-quarantine for } 14 \\
\text { days. }\end{array}$ & \\
\hline Mar 26, 2020 & 21393 & 15865 & $\begin{array}{l}\text { The federal government announced that a US } \\
\text { navy ship hospital would be going to NYC as a } \\
\text { part of relief efforts. }\end{array}$ & $\begin{array}{l}\text { The ship departed from Norfolk on Mar } 28 \text { and arrived on Mar } \\
30,2020 \text {. }\end{array}$ \\
\hline Apr 6, 2020 & 72,181 & 58508 & $\begin{array}{l}\text { Stay-at-home orders and school closures were } \\
\text { extended to Apr } 29 .\end{array}$ & \\
\hline Apr 9, 2020 & 87028 & 72909 & $\begin{array}{l}\text { Golf courses were removed from the list of } \\
\text { essential businesses that were allowed to } \\
\text { remain open. }\end{array}$ & $\begin{array}{l}\text { The bordering States, such as New Jersey and Pennsylvania, } \\
\text { had ordered courses to close. }\end{array}$ \\
\hline Apr 14, 2020 & 110425 & 91783 & $\begin{array}{l}\text { The State Department of Labor was asked to } \\
\text { make an extra } \$ 600 \text { available for } \\
\text { unemployment benefits for New Yorkers. }\end{array}$ & $\begin{array}{l}\text { The federal CARES Act authorized federal funds for the states } \\
\text { to supplement their unemployment benefits, but there were } \\
\text { bureaucratic delays. }\end{array}$ \\
\hline
\end{tabular}


Table II (A): Gaps and challenges at the policy level to combat COVID-19 in New York City.

\begin{tabular}{|c|c|}
\hline Challenges & Implications \\
\hline \multicolumn{2}{|l|}{ Policy level } \\
\hline Neo-liberal capitalism & $\begin{array}{l}\text { The economic and political structure of the society, embracing neoliberal capitalism, became one of the greatest } \\
\text { hurdles in dealing with COVID-19, in NYC. } \\
\text { Respect for basic human rights, such as freedom of movement and personal liberty, kept state officials from delaying } \\
\text { the enforcement of restrictions on mass gatherings, and there was an enormous reluctance in implementing a timely } \\
\text { lockdown and social distancing measures. The government's earlier reluctance to impose a ban on the city's mass } \\
\text { transit system is said to have fiscal roots, as the Metropolitan Transportation Authority generates around } 50 \% \text { of its } \\
\text { approximately } \$ 16.725 \text { billion budget from tolls and the money paid to subway rides and buses. }{ }^{10} \\
\text { The Coronavirus Government Response Tracker, an index developed by Oxford University, has placed the USA among } \\
\text { the lowest achievers (66\%) in the stringency of measures taken to combat COVID-19 in a comparative study involving } \\
\text { six countries. }{ }^{11}\end{array}$ \\
\hline
\end{tabular}

Earlier reliance on herd immunity
The USA relied on herd immunity, like the UK, to preclude the need for taking necessary public health containment measures, costing thousands of lives in the worst affected area, NYC, as well as across the country. ${ }^{12}$
There was no fully authorized central body to supervise and implement mitigation measures as per the available data and expert projections across the states.

Lack of central authority The White House COVID-19 task force had limited capacity to interfere in matters related to the states at an administrative level. Examples include revoking of the White House's suggestions, particularly, by the governors of predominantly Democrat states.
Lack of coordination between federal, state, and city governments

Lack of proactivity

Scarcity of personal protective equipment for health workers and the general population

Shortage of health workforce
Special case of NYC

There was a lack of coordination between federal and state governments, and between the state and the NYC administration.

The federal government was more inclined to assist Republican states with fewer cases than the predominantly democratic New York State.

This lack of coordination caused considerable delays at all levels of the government.

Expert projections revealed that if social distancing policies had been issued two weeks earlier, COVID-19 deaths could be reduced by $90 \%$, throughout the country. ${ }^{13}$

Although California matched with New York in terms of situation, it imposed aggressive stay-at-home orders with just 500 cases statewide.

Till March 19, 2020, New York State's government demonstrated limited insight in placing timely orders of medical supplies. ${ }^{14} \mathrm{~A}$ comparison of the rising number of cases followed by government measures indicates a lack of proactivity and failure to understand the situation.

It was clear from the beginning that the COVID-19 epidemic would cast devastating effects on NYC, if it reached New York State. NYC, with its dense population (27,000 people per square mile), crowded skyscrapers, cultural diversity, the highest frequency of worldwide tourism, busy mass transit system, and economic activity, was most prone to witness an exponential growth of the virus than anywhere else in the state.

However, no special preventive measures were made for the city, and most of the time, the city was treated like the rest of the state, where the population is sparse and traveling is far less frequent.

On Mar 6, 2020, when sanitizers, cleaning solutions, disinfectants, and protective masks and gloves were already disappearing from large department stores, the city government was attributing the shortage to the federal government. According to the press, no extra N95 masks or protective suiting was formally requested by the local government. ${ }^{14}$

By mid-March, 2020, the high rate of COVID-19 transmission indicated that NYC was bound to witness a high death toll owing to COVID-19 within the forthcoming two weeks. Measures taken to compensate for the scarcity of the healthcare workforce in intensive care units were ad hoc with the traditional expectation of relying on volunteers from unaffected regions. No plan was devised for training the healthcare workforce or developing contingency plans to prepare for a possible workforce joining the team, before things became critical. This delay ultimately resulted in negligence and low quality of care in overwhelmed large city hospitals.

Infections were reported from nursing homes. No guidelines were developed to keep unaffected patients, either visiting or already admitted in the care facilities, from those with confirmed COVID-19.

The USA had a slow start in conducting widespread testing for COVID-19. The first US case of COVID-19 of unknown origin could not be tested until after the fourth day of a hospital stay, as he had not fulfilled the initial federal testing criteria. ${ }^{15}$

Testing
There were faulty test kits produced by the CDC in February; further, academic labs in other states were not allowed to devise their own testing kits under federal law.

It would not be possible until March 12, 2020 for the majority of the states to be able to perform tests with a physician's recommendation from the CDC or a commercial lab in the state. ${ }^{16}$ 
Table II (B): Gaps and challenges at the community level to combat COVID-19 in New York City.

\begin{tabular}{|c|c|}
\hline Challenges & Implications \\
\hline \multicolumn{2}{|l|}{ Community level } \\
\hline $\begin{array}{l}\text { Lack of enforcement of } \\
\text { self-quarantine policies }\end{array}$ & $\begin{array}{l}\text { Imposing quarantine policies in low-income groups was a challenge as there was minimal job security for them when work-from- } \\
\text { home laws were not imposed. } \\
\text { Many people in urban slums or low socioeconomic neighborhoods share rooms and dormitories with other workers; therefore, } \\
\text { social isolation was difficult to enforce. } \\
\text { No isolation center was designated to provide quarantine facilities for suspected contacts of cases from such localities. There } \\
\text { were no enclaves for homeless people in NYC. }\end{array}$ \\
\hline Orthodox communities & $\begin{array}{l}\text { It was estimated that up to } 28 \% \text { of people in orthodox religious communities, such as Hasidic Jews, had tested positive in NYC, } \\
\text { which linked back to congregations in synagogues. }\end{array}$ \\
\hline $\begin{array}{l}\text { Influx of NYC residents } \\
\text { to upstate New York }\end{array}$ & $\begin{array}{l}\text { With a surge of COVID-19 cases in the city, affluent residents of NYC showed an increased tendency to relocate themselves in the } \\
\text { upstate countryside of New York State. As cases in the countryside appeared to be linked to relocated city residents, local } \\
\text { administrations expressed resentment, urging the state government to ban any such relocations from NYC. }\end{array}$ \\
\hline
\end{tabular}

Morbidity trends were high among healthcare workers because they were not allowed to stay at home despite having COVID-19 symptoms. ${ }^{5}$ Four state legislatures tested positive. In the state police department, $7.6 \%$ of employees were affected by COVID-19; 7 police officers had died from the virus by the end of the first week of April. ${ }^{6}$ According to the excess mortality analysis, during March, there were three times more deaths than expected in NYC. Recent studies have suggested that the virus was present in NYC in February 2020, and the studies have traced its origins to European tourism rather than to China. ${ }^{7,8}$

\section{Government measures:}

The measures and actions taken by the three tiers of government are time lined in Table I.

\section{Analysis of response gaps and challenges at the policy and community levels to combat COVID-19 in New York City:}

Analyses of response gaps and challenges faced at the policy and community levels to combat the spread of COVID-19 in NYC are outlined in Tables IIA and IIB.

\section{The way forward:}

This study highlights the importance of proactive and timely preventive measures for megacities in other countries that are also potentially threatened by the worsening epidemic.

The procurement of essential medical and protective equipments and enhancement of testing capacity and rapidity are necessary for combating the current situation.

The maximum amount of resources should be diverted to cater to the needs of low-income groups in lockdown situations.

Major lockdowns should be continued until flattening, followed by tapering, of the epidemic curve is satisfactorily achieved across the country.

The next step toward lifting statewide lockdowns should be very gradual and vigilant. Suggestions have already emerged that before allowing people back to normal life, universal screening should be conducted for COVID-19. Additionally, antibody testing of convalescent cases should be performed at the community level to allow the immune population to rejoin regular life activities and break the chain of transmission. Similar testing has recently been performed by researchers from Australia, Finland, and New York's Mt. Sinai Medical School. At this point, the government and Centers for Disease Control (CDC) should step in to identify cost-effective ways to conduct such testing on a large scale.

Community testing sites or drive-through testing should be introduced for minimising the risk of exposure to the health workforce.

There is a dire need for proactive decision-making based on robust data projections about COVID-19 trends.

The exemplary measures taken by SARS-affected countries in 2004, as well as the current initiatives adopted by countries such as South Korea, Taiwan, and Singapore who have successfully contained current pandemic locally, should be reviewed and implemented as appropriate in locally appropriate context. ${ }^{17,18}$

The maximum possible amount of resources needs to be diverted at the state and country levels for the research and development of effective COVID-19 vaccines and medicines.

An important requirement would be to keep a sensitive public health surveillance system in place to capture any possible second wave of the disease at travelers' entry points and the community and hospital levels.

\section{CONFLICT OF INTEREST:}

Authors declared no conflict of interest.

\section{AUTHORS' CONTRIBUTION:}

AZ: Conceived the idea of the study and developed first draft. MI, SWH: Provided intellectual contribution and participated in reviewing and editing of subsequent drafts.

All three authors approved the final version.

\section{REFERENCES}

1. Worldometers. (2020) [Internet]. Coronavirus cases. Retrieved from http://www.worldometers.info/coronavirus/

2. Lau H, Khosrawipour V, Kocbach P. Internationally lost 
COVID-19 cases. [published online ahead of print, 2020 Mar 14]. J Microbiol Immunol Infect 2020; S1684-1182(20): 30073-6.

3. The Centers for Disease Control and Prevention (CDC, 2020) (Centers for Disease Control and Prevention [CDC], 2020). Retrieved from http://www.cdc.gov/coronavirus/2019-ncov/cases-updates/c ases-in-us.html

4. WHO. Rolling updates on coronavirus disease (COVID-19) updated 9 April 2020. Retrieved from http://www.who.int/emergencies/diseases/novel-coronavirus -2019/events-as-they-happen.

5. Edelman S and Moore T. "NYC first responders resent lack of coronavirus equipment". New York Post. March 21, 2020. Archived from the original on March 22, 2020. Retrieved April 13 , 2020. http://nypost.com/2020/03/21/nyc-first-responders-resent-la ck-of-coronavirus-equipment/

6. Rayman G. "Police union files complaint with state over alleged NYPD failure to issue personal protective gear to cops during coronavirus outbreak". March 13, 2020. Archived from the original on April 13, 2020. Retrieved March 22, 2020.

7. Katz, Josh, Sanger-Katz, Margot (April 10, 2020). "Deaths in New York City Are More Than Double thttp://www.nydailynews.com/new-york/nyc-crime/ny-policeunion-coronavirus-equipment-20200313-2dlyg6nwuzerpj7wmw4wsu5spy-story.htmlhe Usual Total". The New York Times. Retrieved April 10, 2020. http://www.nytimes.com/interactive/2020/04/10/upshot/coro navirus-deaths-new-york city.html

8. Rodriguez-Morales AJ, Balbin-Ramon GJ, Rabaan AA, Sah R, Dhama K, Paniz-Mondolfi A, et al. Genomic epidemiology and its importance in the study of the COVID-19 pandemic. Infez Med 2020; 28(2):139-142.

9. Dot Chinese Online \& Dot Chinese Website, the essential new Chinese TLDs - Infographic: Where in the World Do
Chinese People Live? Retrieved from http://www. circleid.com/posts/20141001_infographic_where_in_the_world_do_chinese_people_live/

10. MTA Operating Budget Basics. Retrieved from http://new.mta.info/budget/MTA-operating-budget-basics.

11. Hale, Thomas, Sam Webster, Anna Petherick, Toby Phillips, Beatriz Kira. Oxford COVID-19 Government Response Tracker, Blavatnik School of Government. Data use policy: Creative Commons Attribution CC BY standard 2020.

12. John Hopkins School of Public Health Expert insights: What is Herd Immunity and How Can We Achieve It With COVID-19? Retrieved from http://www.jhsph.edu/covid-19/ articles/achieving-herd-immunity-with-covid19.html

13. Fraser C1, Riley S, Anderson RM, Ferguson NM. Factors that make an infectious disease outbreak controllable. Proc Natl Acad Sci USA 2004; 101(16):6146-51.

14. John Hopkins School of Public Health Expert insights: Recommendations for a Metropolitan COVID-19 Response. Retrieved from: http://www.jhsph.edu/covid-19/articles/covid-19-recommendations-for-a-metropolitan-response.html

15. Adalja AA, Toner E, Inglesby TV. Priorities for the US health community responding to COVID-19. JAMA 2020; 323(14): 1343-4.

16. "COVID-19 Testing - New York Department of Health". April 13, 2020. Retrieved from http://coronavirus.health.ny.gov/covid-19-testing

17. FDA. Coronavirus (COVID-19) update: FDA issues new policy to help expedite availability of diagnostics. February 29, 2020 .

http://www.fda.gov/news-events/press-announcements/coro navirus-covid-19-update-fda-issues-new-policy-help-expedite-availability-diagnostics

18. Ferguson N, Cummings D, Cauchemez S, Fraser C, Riley S, Meeyai $A$, et al. Strategies for containing an emerging influenza pandemic in Southeast Asia. Nature 2005; 437 (7056):209-14. 